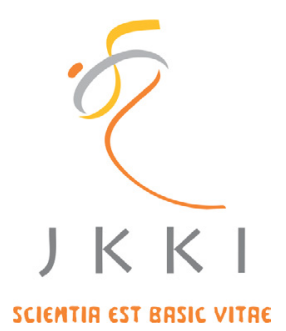

Jurnal Kedokteran dan Kesehatan Indonesia

Indonesian Journal of Medicine and Health

Journal homepage : www.journal.uii.ac.id/index.php/JKKI

\title{
The prevalence of dermatological infection in outpatient dermatology clinic of RSUD Wonosari in January-September 2016
}

\author{
Trijanto Agoeng Noegroho ${ }^{1}$, Rosmelia ${ }^{2}$, Lamya Muthia Nabila*2 \\ ${ }^{1}$ RSUD Wonosari, Yogyakarta, Indonesia \\ ${ }^{2}$ Faculty of Medicine, Islamic University of Indonesia
}

Original Article

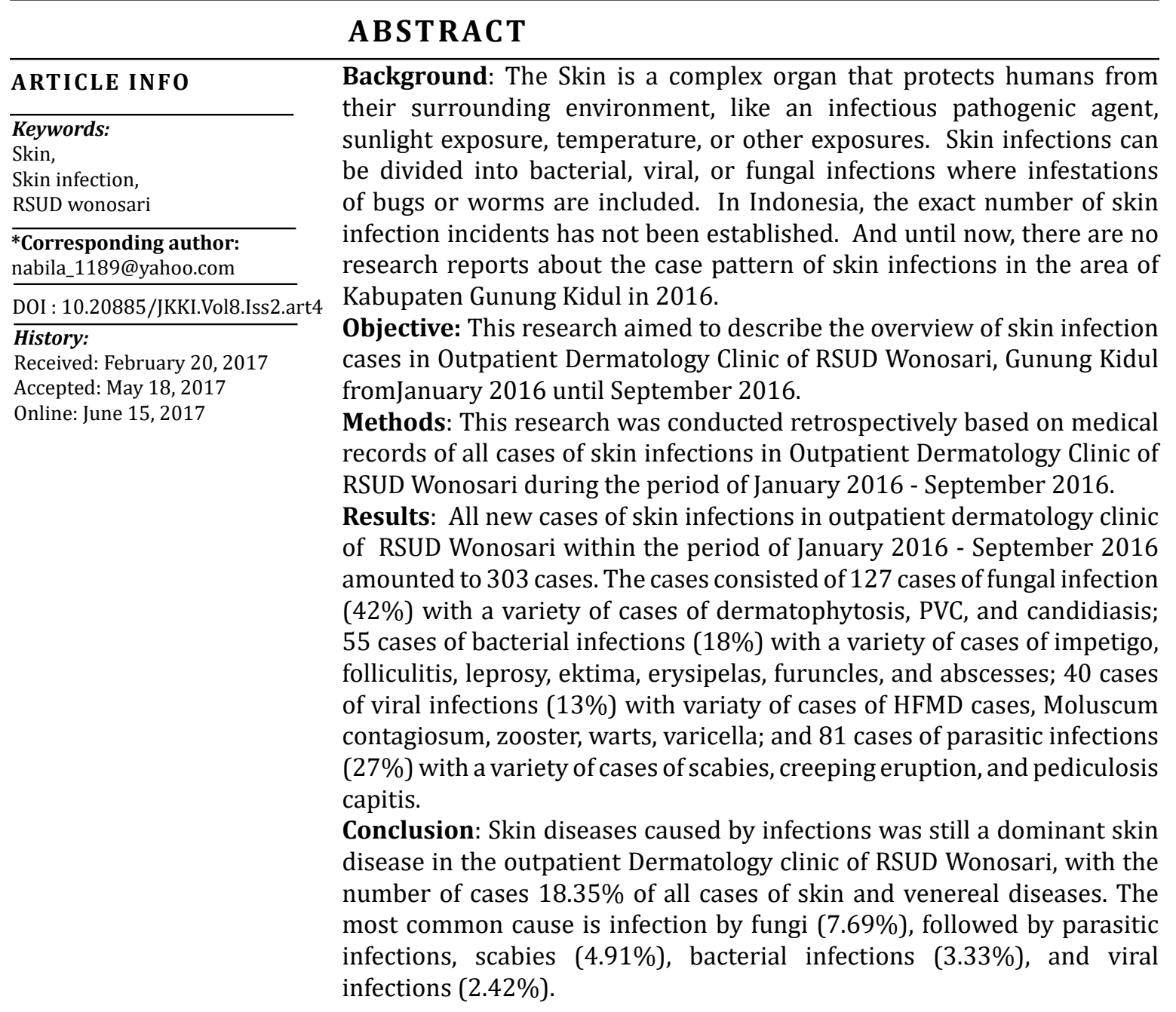

Latar Belakang: Kulit merupakan organ kompleks yang melindungi seseorang dari lingkungan sekitarnya seperti agen patogenik yang infeksius, paparan sinar matahari, suhu maupun paparan lainnya. Infeksi kulit dapat dibagi menjadi infeksi bakteri, virus, atau jamur dimana infestasi dengan serangga atau cacing juga termasuk di dalamnya. Di Indonesia, angka yang tepat untuk insidensi cases infeksi kulit belum ada. Dan sampai saat ini belum ada laporan penelitian mengenai pola cases infeksi kulit di daerah Kabupaten 
Gunung Kidul Khususnya di RSUD Wonosari tahun 2016.

Tujuan: Penelitian ini bertujuan untuk mengetahui gambaran umum cases infeksi kulit pada instalasi rawat jalan Poliklinik Kulit dan Kelamin RSUD Wonosari, Gunung Kidul periode January 2016 September 2016.

Metode: Penelitian dilakukan secara cross sectional berdasarkan catatan medis seluruh cases infeksi kulit pasien rawat jalan Poli klinik Kulit dan Kelamin RSUD Wonosari selama periode January 2016 - September 2016.

Hasil: Seluruh cases baru infeksi kulit di instalasi rawat jalan Poliklinik Kulit dan Kelamin RSUD Wonosari periode January 2016 - September 2016 berjumlah 303 cases. Cases tersebut terdiri dari 127 cases infeksi jamur (42\%) dengan variasi cases dermatophytosis, PVC, dan candidiasis ; 55 cases infeksi bakteri (18\%) dengan variasi cases impetigo, folikulitis, lepra, ektima, erisipelas, furunkel, dan abses; 40 cases infeksi virus (13\%) dengan variasi cases HFMD, Moluscum contagiosum, zooster, veruka, varicela; dan 81 cases infeksi parasit (27\%) dengan variasi cases scabies, creeping eruption, dan pediculosis capitis.

Kesimpulan: Penyakit kulit yang disebabkan infeksi masih merupakan penyakit yang mendominasi pada pasien Poli Kulit dan Kelamin di RSUD Wonosari, dengan jumlah cases 18,35\% dari keseluruhan cases penyakit kulit dan kelamin. Penyebab yang paling sering adalah infeksi oleh jamur (7,69\%), diikuti infeksi parasit, scabies $(4,91 \%)$, infeksi bakteri $(3,33 \%)$ dan virus $(2,42 \%)$.

\section{INTRODUCTION}

The skin is a complex organ that protects human beings from their surroundings, such as: infectious pathogenic agent, exposure to sun rays, temperatures, or other exposures. ${ }^{1}$ Infections originated from the word inficere which is defined as pathological microorganisms invasion to the body that reproduces and multiply, causing diseases through local cellular damage, secreting toxin, or antigen-antibody reactions in the host. ${ }^{2}$

Dermatological infections can be classified into bacterial, viral, fungal, and parasitic infections in which the infestations of bugs or worms are included. ${ }^{3}$ Many of these infections and infestations are universal in nature, for instance, herpes simplex, varicella, herpes zoster, papilloma viral infection, bacterial infections of Staphylococcus, Streptococcus, dermatophytes infections, as well as scabies. Other diseases that are included in tropical infections include leprosy, subcutaneous fungal and protozoal infections. Many of these diseases are affected by tropical climate and the presence of various bugs within the area. ${ }^{4}$ Hot and humid climate is a predisposition factor for fungal, bacterial, and parasitic infections. ${ }^{5}$ It is of course very important for a country to determine which disease has the highest prevalence in its area. ${ }^{4}$

In Indonesia, the exact number for the incidence of dermatological infections is still nonexistent. The incidence is presumed to be similar to the incidence in the larger cities of Indonesia. Based on the data taken from various Teaching Hospitals in Indonesia within the year of 1997 -1998, the highest incidence of fungal infection was dermatophytes, followed by Pityriasis Versicolor, and cutaneous candidiasis in third place. ${ }^{6}$ In some hospitals (Ujung Pandang, Medan, dan Denpasar), the incidence of cutaneous candidiasis might be higher than Pityriasis Versicolor. In contrary to a study by Budimulja from Jakarta in 1989 and Dhiana Ernawati et al from Semarang in 1994, pityriasis Versicolor had the highest incidence, followed by dermatophytes and cutaneous candidiasis. Until now, there has not been any study about the pattern of dermatological infections in Kabupaten Gunung Kidul in 2016. This study aims to determine the general description of dermatological infections in Outpatient Dermatology Clinic of RSUD Wonosari, Gunung Kidul, within the period of January 2016 - September 2016.

\section{METHODS}

This study is a cross-sectional study using the medical records of all patients with dermatological infections in Outpatient Dermatology Clinic of RSUD Wonosari within the period of January 2016-September 2016. The diagnosis was based on anamnesis, clinical examination, and simple clinical procedures. Fungal examinations were done using $\mathrm{KOH}$ preparation and were observed 
under the microscope with low magnification. Fungal infections were recognized based on the presence of hypha, pseudohyphae or spores. Data were analyzed using SPSS Statistic 21.

\section{RESULTS}

All cases of new dermatological infections in Outpatient Dermatology Clinic of RSUD Wonosari during January 2016 - September 2016 was counted and amounted to 303 cases. Figure 1 showed the distributions of dermatological infections during the research in that period. Fungal infections were found the most, which was $42 \%$ of total cases, followed by parasitic infections which were $27 \%$ of total cases (Figure 1).

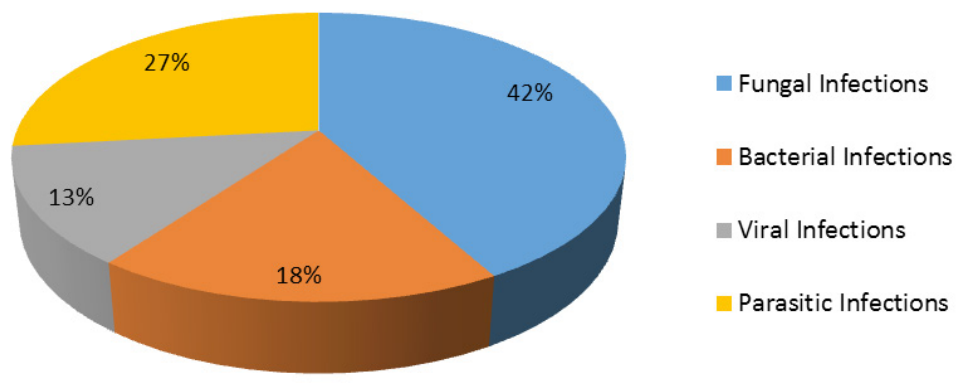

Figure 1. The Distributions of New Dermatological Infections in Outpatient Dermatology Clinic of RSUD Wonosari

The distribution based on gender was found more in male, 59,05\% for fungal infection, $60,00 \%$ for bacterial infection, and $65,43 \%$ for parasitic infection. There was no difference in prevalence of viral infection in male and female (Table 1).

Table 1. Distribution of Dermatological Infections based on Gender in Outpatient Dermatology Clinic of RSUD Wonosari from January 2016 - September 2016

\begin{tabular}{lccr}
\hline Types of infection & Male & Female & \multicolumn{1}{c}{ Total } \\
\hline Fungal & $75(59,05 \%)$ & $52(40,95 \%)$ & $127(100 \%)$ \\
Bacterial & $33(60,00 \%)$ & $22(40,00 \%)$ & $55(100 \%)$ \\
Virus & $20(50,00 \%)$ & $20(50,00 \%)$ & $40(100 \%)$ \\
Parasit & $53(65,43 \%)$ & $28(34,57 \%)$ & $81(100 \%)$ \\
Total & $181(59,74 \%)$ & $122(40,26 \%)$ & $303(100 \%)$ \\
\hline
\end{tabular}

The distribution of new cases of fungal infections was mostly due to dermatophytes, amounted to 96 cases $(75,59 \%)$, in which age group 15-64 years old had the highest number of case, 69 cases (71,88\%). Pityriasis Versicolor caused by Malassezia furfur was in second place with 22 cases (17,32\%), in which age group15-64 years old had the highest number of case, 14 cases $(63,64 \%)$. Candidiasis caused by Candida albicans was next, with 9 cases $(70,87 \%)$, in which 0-4 years old had the highest number of case, 6 cases $(66,67 \%)$ (Table 2).
The distribution of new cases of parasitic infections was found mostly due to Sarcoptes scabiei (scabies) which was 76 cases $(93,83 \%)$ in which the age group 15-64 years old had the most number of case, 44 cases $(57,89 \%)$. Pediculosis capitis had 1 case and there were 4 cases of creeping eruption (Table 3).

The distribution of case for bacterial infection was mostly caused by folliculitis, which had 16 cases $(29,09 \%)$, in which the age group 5-14 years old had the most cases, 6 cases $(37,50 \%)$. Leprosy was in second place, amounted to 14 
cases $(25,45 \%)$, in which the age group of $15-64$ years old had the most case with 11 cases $(78,57$ $\%)$. Impetigo was next with $20,00 \%$, in which the age group of 0-4 years old had the most case with 7 cases $(63,64 \%)$. Eczema was fourth with 7 cases (12,73\%), mostly in the age group 15-64 years old (42,86\%). Erysipelas 4 cases, furuncle 2 cases, and abscess 1 case were next, amounted to 7 cases $(12,73 \%)$ (Table 4$)$

The distribution of cases for viral infection showed that Zoster had the most case, which was 19 cases $(47,50 \%)$, in which the age group of 15-64 years old had the most number of cases, 16 cases $(84,21 \%)$. Hand foot and mouth disease (HFMD) was next with 9 cases $(22,50 \%)$, in which the age group of $0-4$ years old had the most number of cases $(77,78 \%)$. Verruca had 8 cases $(20,00 \%)$ in which the age group with the most case was $15-64$ years old $(87,50 \%)$. Varicella had 3 cases and molluscum contagiosum had 1 case.(Table 5)

Table 2. Case Distribution for Fungal Infections Based on Etiology, Gender, and Age Group

\begin{tabular}{lrrrrrrr}
\hline \multicolumn{1}{c}{ Etiology } & \multirow{2}{*}{ Male } & \multirow{2}{*}{ Female } & $\mathbf{0 - 4}$ & $\mathbf{5 - 1 4}$ & $\mathbf{1 5 - 6 4}$ & $\mathbf{2 6 5}$ & Total \\
\hline Dermatophytosis & 55 & 41 & 0 & 9 & 69 & 18 & 96 \\
PVC & 16 & 6 & 1 & 6 & 14 & 1 & 22 \\
Candidiasis & 4 & 5 & 6 & 0 & 2 & 1 & 9 \\
Total & 75 & 52 & 7 & 15 & 85 & 20 & 127 \\
\hline
\end{tabular}

Table 3. Case Distribution of Parasitic Infections based on Etiology, Gender, and Age Group

\begin{tabular}{lrrrrrrr}
\hline \multicolumn{1}{c}{ Etiology } & \multirow{2}{*}{ Male } & \multirow{2}{*}{ Female } & $\mathbf{0 - 4}$ & $\mathbf{5 - 1 4}$ & $\mathbf{1 5 - 6 4}$ & $\mathbf{2 6 5}$ & Total \\
\hline Scabies & 51 & 25 & 9 & 23 & 44 & 0 & 76 \\
Creeping eruption & 2 & 2 & 1 & 1 & 2 & 0 & 4 \\
Pediculosis capitis & 0 & 1 & 0 & 1 & 0 & 0 & 1 \\
Total & 53 & 28 & 10 & 24 & 46 & 0 & 81 \\
\hline
\end{tabular}

Table 4. Case distribution for Bacterial Infection Based on the Etiology, Gender, and Age Group

\begin{tabular}{lrrrrrrr}
\hline \multicolumn{1}{c}{ Etiology } & Male & Female & $\mathbf{0 - 4}$ & $\mathbf{5 - 1 4}$ & $\mathbf{1 5 - 6 4}$ & $\mathbf{2 6 5}$ & Total \\
\hline Impetigo & 4 & 7 & 7 & 4 & 0 & 0 & 11 \\
folliculitis & 10 & 6 & 3 & 6 & 5 & 2 & 16 \\
Leprosy & 11 & 3 & 0 & 1 & 11 & 2 & 14 \\
Eczema & 6 & 1 & 2 & 2 & 3 & 0 & 7 \\
Erysipelas & 0 & 4 & 0 & 0 & 4 & 0 & 4 \\
Furuncle & 1 & 1 & 2 & 0 & 0 & 0 & 2 \\
Abscess & 1 & 0 & 0 & 0 & 0 & 1 & 1 \\
Total & 33 & 22 & 14 & 13 & 23 & 5 & 55 \\
\hline
\end{tabular}


Table 5. Case Distribution of Viral Infection Based On Etiology, Gender And Age

\begin{tabular}{lccccccc}
\hline \multicolumn{1}{c}{ Etiology } & \multirow{2}{*}{ Male } & \multirow{2}{*}{ Female } & \multicolumn{5}{c}{ Age (Years) } \\
& & & $\mathbf{0 - 4}$ & $\mathbf{5 - 1 4}$ & $\mathbf{1 5 - 6 4}$ & $\mathbf{2 6 5}$ & Total \\
\hline HFMD & 4 & 5 & 7 & 2 & 0 & 0 & 9 \\
Molluscum contagiosum & 1 & 0 & 0 & 1 & 0 & 0 & 1 \\
Zoster & 9 & 10 & 0 & 0 & 16 & 3 & 19 \\
Verruca & 6 & 2 & 0 & 0 & 7 & 1 & 8 \\
Varicella & 0 & 3 & 0 & 2 & 1 & 0 & 3 \\
Total & 20 & 20 & 7 & 5 & 24 & 4 & 40 \\
\hline
\end{tabular}

\section{DISCUSSION}

Based on the medical reports of patients in Outpatient Dermatology Clinic of RSUD Wonosari within the research period, the number of patients suffering from skin infection was 303 patients $(18,35 \%)$ over 1.651 patients who were treated in the dermatology clinic within the research period. The cases caused by viral infection was $2,42 \%$, bacterial infection was $3,33 \%$, superficial fungal infection was $7,69 \%$, and parasite infection was $4,91 \%$ overall outpatients being treated in the Dermatology clinic within the research period.

A previous retrospective research in outpatient dermatology clinic of RSUP Dr. Kariadi Semarang, which was done for 3 years (20082010), showed that the amount of patients treated with dermatological infection was 3154 orang $(33,52 \%)$ over 9409 patients who were being treated in the dermatology clinic. Viral infection cases was 9,53\%, bacterial infection was $6,21 \%$, and superficial fungal infection was $17,78 \%$ over all patients being treated in the outpatient dermatology clinic of RSUP Dr. Kariadi. $^{7}$

A previous cross sectional study about the case distribution of skin infection in outpatient dermatology clinic of RSUD Dr. Moewardi Surakarta, showed that the number of cases for skin infections during October 2010 - September 2011 was 533 cases of fungal infection (55\%), followed by 177 cases of bacterial infections (18\%), 139 cases of viral infections (14\%), and 131 cases of parasitic infections (13\%), no data about the number of total dermatology patients during the research period was being described. ${ }^{8}$
Superficial fungal infection was found the most $(7,69 \%)$ over all skin diseases within the period January 2016 - September 2016 in RSUD Wonosari. Dermatophytosis was the type of superficial fungal infection that was found the most $(75,59 \%)$ followed by pityriasis versicolor $(17,32 \%)$ and cutaneous candidiasis $(7,09 \%)$. A previous retrospective study conducted by Ayamiseba et al from RSUP Prof. Dr. RD Kandou Manado in July 2006-June 2010, found that the prevalence of superficial dermatophycosis was $18,15 \%$, while another research by Raflis et al from secondary hospital RS dr. Achmad Mochtar Bukit tinggi in 2007-2010 found that the prevalence of superficial dermatophytosis was 7,29\%. 9,10 Another research in Semarang within the period October 2010 until September 2011 found that dermatophytosis was the kind of fungal infection mostly found during the research period $(39,27 \%)$ followed by pityriasis versicolor (34,73\%) and cutaneous candidiasis (26\%).7

Based on the cross sectional data in RSUD Wonosari within the period of January 2016 September 2016 Folliculitis had the most case among bacterial skin infections which amounted to 16 cases $(15,69 \%)$, followed by leprosy 16 cases $(15,69 \%)$ and impetigo 11 cases $(10,78 \%)$. Impetigo occured mostly in the age group of 0-4 years old which amounted to 7 cases $(63,64 \%)$. This is probably due to a combination of pediatric skin integrity (children's skin are easily scratched because of their activities) skin moisture, ceratinization, bacterial virulence, children's lack of hygiene, and immature immune system. In children who live in a hot and humid climate, Streptococcus infection in the skin could 
be found more often. This research showed that there was no difference in prevalence between male and female.

Scabies had the highest amount of cases among other parasite infections in RSUD Wonosari, amounted to 76 cases $(98,82 \%)$ of all skin parasite infestations. Most cases were related to pesantren or family members staying in a pesantren. The circumstances in a pesantren usually conditioned their students to live together in one packed room, thus allowing close contact and ease the transmition of scabies as well as hindering its eradication.

Zoster had the highest amount of cases among other viral infections, amounted to 19 cases (47,50\%), followed by Hand Foot And Mouth Disease 9 cases $(22,50 \%)$ and varicella 9 cases $(16,37 \%)$. The distribution of zoster cases was even accross the year, as well as veruca, and the prevalnce between male and female was equal.

\section{CONCLUSION}

Based on the cross-sectional research conducted inRSUD Wonosari within the period ofJanuary 2016 - September 2016, it was found that dermatological infections were still a dominant disease, in which the number of the case was $18,35 \%$ overall skin diseases being treated. The most common etiology was fungal infection $(7,69 \%)$, followed by parasite infection, scabies $(4,91 \%)$, bacterial infections $(3,33 \%)$ and viral infections $(2,42 \%)$.

\section{REFERRENCE}

1. Chu DH. Development and structure of the skin. In: Wolff K, Goldsmith L, Katz S, Gilchrest B, Paller AS, Leffell D, editors. Fitzpatrick's dermatology in general medicine. 7th ed. New York: McGraw-Hill; 2008. p. 57-72.

2. Mosby. Medical dictionery. 8th ed. USA: Elsevier; 2009.

3. English JSC. An Atlas of dermatology and management general dermatology. United Kingdom: Clinical Publishing Oxford; 2007. $113 \mathrm{p}$.

4. Tyring SK, Lupi O, Hengge UR. Tropical der- matology. 1st ed. London: Elsevier Churchill Livingstone; 2006.515 p.

5. Naafs B, Padovese V. Rural dermatology in the tropics. Clinics in Dermatology. 2009;27(3):252-70.

6. Adiguna MS. Epidemiologi dermatomikosis di Indonesia. In: Budimulija U, editor. Dermatomikosis superfisialis. Jakarta: Balai Penerbit FKUI; 2003. p. 1-4.

7. Anggraeni P, Radityastuti. Karakteristik penyakit kulit akibat infeksi di poliklinik kulit dan kelamin RSUP Dr. Kariadi Semarang periode January 2008-Desember 2010. Universitas Diponegoro; 2001.

8. Sansan MV, Julyanto I, Mawardi P. Tinjauan retrospektif infeksi kulit di instalasi rawat jalan poliklinik kulit dan kelamin RSUD Dr. Moerwadi Surakarta periode October 2010-September 2011. Surakarta; 2011. 